\title{
QTL mapping of soybean oil content for marker-assisted selection in plant breeding program
}

\author{
D.C. Leite ${ }^{1}$, J.B. Pinheiro' ${ }^{2}$, J.B. Campos ${ }^{2}$, A.O. Di Mauro ${ }^{1}$ and \\ S.H. Unêda-Trevisoli ${ }^{1}$ \\ ${ }^{1}$ Laboratório de Biotecnologia Aplicada ao Melhoramento de Plantas, \\ Faculdade de Ciências Agrárias e Veterinárias, \\ Universidade Estadual Paulista "Júlio de Mesquita Filho", Jaboticabal, SP, Brasil \\ "Laboratório de Diversidade Genética e Melhoramento de Plantas, \\ Universidade de São Paulo, Escola Superior de Agricultura "Luiz de Queiroz", \\ Piracicaba, SP, Brasil \\ Corresponding author: D.C. Leite \\ E-mail: danielcarvalholeite@hotmail.com
}

Genet. Mol. Res. 15 (1): gmr.15017685

Received September 18, 2015

Accepted November 19, 2015

Published March 18, 2016

DOI http://dx.doi.org/10.4238/gmr.15017685

\begin{abstract}
The present study was undertaken to detect and map the quantitative trait loci (QTL) related to soybean oil content. We used 244 progenies derived from a bi-parental cross of the Lineage 69 (from Universidade Estadual Paulista "Júlio de Mesquita Filho"/Faculdade de Ciências Agrárias e Veterinárias - Breeding Program) and Tucunaré cultivar. A total of 358 simple sequence repeat (SSR; microsatellite) markers were used to investigate the polymorphism between the parental lines, and for the polymorphic lines all the $F_{2}$ individuals were tested. Evaluation of the oil content and phenotype was performed with the aid of a Tango equipment by near infra-red reflectance spectroscopy, using single $F_{2}$ seeds and $F_{2: 3}$ progenies, in triplicate. The data were analyzed by QTL Cartographer program for 56 SSR polymorphic markers. Two oil-content related QTLs were detected on $\mathrm{K}$ and $\mathrm{H}$ linkage groups. The total phenotypic variation
\end{abstract}


explained by QTLs ranged from 7.8 to $46.75 \%$ for oil content. New QTLs were identified for the oil content in addition to those previously identified in other studies. The results reported in this study show that regions different from those already known could be involved in the genetic control of soybean oil content.

Key words: Glycine max; SSR; NIR; Molecular markers

\section{INTRODUCTION}

Soybean has a well-established supply chain and wide application throughout Brazil, mainly due to the rapid and continuous progress in breeding programs that are underway across the country, which enabled the effective production of the crop all over the country, contributing to a breakdown of agricultural boundaries.

Through the advances in breeding programs in recent decades, several technologies have been incorporated to affect the delivery of new cultivars. Thus, use of molecular marker has the potential for identifying genes of agronomic interest in the breeding programs.

The vast majority of the economically important traits are of quantitative nature. Those traits of which the phenotypic expression displays continuous variation are attributed to simultaneous segregation of many genes within the genome. Chromosomal regions defining the location of such genes are defined as quantitative trait loci (QTLs).

Microsatellite or simple sequence repeat (SSR) marker is a sequence with one to six base pairs repeated in tandem. SSRs are multiallelic, co-dominant, and are easily detected by polymerase chain reaction (PCR); they are relatively abundant, have extensive genome coverage, and require a low amount of DNA for amplification (Powell et al., 1996).

Linkage genetic map construction through molecular markers can support strategies to be incorporated into the breeding programs to estimate which (and how many) QTLs are responsible for trait variation and to locate their position within the genome, as well as to evaluate their effects and inter-relationships. Development of microsatellite markers in soybean has been carried out for use in genetic mapping. These markers enable candidate genes to be linked to agronomic traits of interest. These markers are considered ideal for assisted selection process because of their benefits (Cato et al., 2001).

Thus, a direct application of genetic map construction is to locate economically important genes or QTLs. Furthermore, genetic mapping allows marker-assisted selection (MAS) in plant breeding programs involving selection, thereby, reducing time and resources spent in developing new cultivars.

Few reports have already described QTLs for soybean oil content using different markers, plant population types and sizes, as well as exotic and adapted genotypes (Panthee et al., 2005; Nichols et al., 2006; Shibata et al., 2008).

With the advent of molecular markers, it became possible to identify such QTL regions that affect quantitative traits. Therefore, mapping a QTL means to detect its position within the genome and to estimate its genetic effects in the adopted model, such as being additive and dominant, among others (Toledo et al., 2008).

Responding to the market demand for soybean cultivars with high oil content, breeding programs focus on the development of varieties with good agronomic traits, early cycle, and high 
oil content to replace the obsolete existing ones. This fact is of great importance, especially in areas with sugarcane cultivation, where soybean could be an option for growing in reform areas as well as for biodiesel production or industrial use.

The present research was, therefore, undertaken to detect the quantitative trait loci associated with soybean oil content in $\mathrm{F}_{2: 3}$ populations derived from the cross between early lineages and those adapted for sugarcane-soybean rotation (having low oil content) as well as genotypes not adapted to this system (having high oil content); the aim of the study was to use them in the selection of the segregating populations for soybean breeding programs.

\section{MATERIAL AND METHODS}

\section{Growth conditions and generation of $F_{2}$ segregating populations}

Artificial breeding (hybridization) was carried out under greenhouse conditions to generate new soybean populations for use in genetic mapping and for selection of new genotypes.

Parents selected for crossings showed earliness, superior agronomic traits, resistance to main soybean diseases, and good seed oil content. The genotypes (L69, L23, L54, L62, L01, L02, L52, L53, and L70) that were used as sources for precocity and agronomic superiority belonged to the breeding program from Universidade Estadual Paulista "Júlio de Mesquita Filho" (UNESP), Jaboticabal. Two commercial cultivars with high oil content (FMT Tucunaré and UFUs Carajás) were also included in the study. During the crossings, trait contrasts were observed for greater variability exploitation (Table 1 ).

Table 1. List of parents used in the crossings along with a description of important traits of each genotype.

\begin{tabular}{|c|c|c|}
\hline Parents & Cycle & Trait \\
\hline Lineage 69 & Up to 120 days (early) & Full adaptation; yield \\
\hline Lineage 23 & Up to 120 days (early) & Full adaptation; yield \\
\hline Lineage 54 & Up to 120 days (early) & Full adaptation; yield \\
\hline Lineage 62 & Up to 120 days (early) & Full adaptation; yield \\
\hline Lineage 01 & Up to 120 days (early) & Full adaptation; yield \\
\hline Lineage 02 & Up to 120 days (early) & Full adaptation; yield \\
\hline Lineage 52 & Up to 120 days (early) & Full adaptation; yield \\
\hline Lineage 53 & Up to 120 days (early) & Full adaptation; yield \\
\hline Lineage 70 & Up to 120 days (early) & Full adaptation; yield \\
\hline FMT Tucunaré & $125-130$ days (medium) & High oil content \\
\hline PI 200487 (Kinoshita) & $131-140$ days (medium) & SR (R) \\
\hline PI 471096 (Orba) & $131-140$ days (medium) & SR (R) \\
\hline Bragg & $131-140$ days (medium) & $\mathrm{MI}(\mathrm{R}), \mathrm{MJ}(\mathrm{R})$ \\
\hline BRS Sambaíba & $131-140$ days (medium) & SR (MR), SB (R) \\
\hline MG/BR 46 (Conquista) & 131-140 days (medium) & SB (R), O (R) \\
\hline IAC 17 & Up to 120 days (early) & SB (R), O (R) \\
\hline IAC Foscarin 31 & Up to 120 days (early) & SB (MR) \\
\hline BRSMG Confiança & Up to 120 days (early) & SB (R), O (R) \\
\hline BRSMG Renascença & $121-130$ days (semi-early) & SCN (R 3), SB (R), O (R), MI (R) \\
\hline BRS 231 & $121-130$ days (semi-early) & SCN (R 3), SB (R) \\
\hline FMT Matrinxã & $121-130$ days (semi-early) & $\operatorname{SCN}(R 1,3), S B(R), M I(R)$ \\
\hline FT-Cometa & Up to 120 days (early) & $\mathrm{MI}(\mathrm{MR}), \mathrm{MJ}(\mathrm{R})$ \\
\hline IAC 23 & Up to 120 days (early) & SB (R), O (R) \\
\hline UFUs Carajas & 115 days (early) & High oil content \\
\hline
\end{tabular}


Artificial hybridizations were performed in an air-conditioned greenhouse in the Department of Crop Production at UNESP/FCAV, Jaboticabal, SP, Brazil. The temperature and relative humidity in the greenhouse was controlled to nearly simulate the environmental conditions of the field. Sowing was done every 7 to 10 days to synchronize the blooming among the parents; viable flower buds of different genotypes were produced to act as male and/or female parents. Five-liter pots filled with a mixture of soil, sand, and vermiculite provided the substrate. Five seeds of each genotype were sown per pot in triplicate; after thinning three plants remained in each pot. These plants were grown vertically and used for hybridization. Seeds obtained from the artificial hybridizations were selected and sown to obtain segregating populations $\left(\mathrm{F}_{2}\right)$.

\section{Genomic DNA extraction and quantification}

Total genomic DNA was extracted from the youngest trifoliate leaf tissue by the CTAB method (cetyltrimethylammonium bromide) adapted for soybean as described by Ferreira and Grattapaglia (1998). The DNA samples were spectrophotometrically quantified using a Nanodrop ${ }^{\circledR}$ (NanoDrop Technologies LLC, Wilmington, DE, USA). The DNA quality was assessed by measuring its absorbance at 260 and $280 \mathrm{~nm}$.

DNA extracted from $\mathrm{F}_{1}$ and $\mathrm{F}_{2}$ populations was used to identify and confirm the hybridized plants for further use in the genetic mapping of QTLs for seed oil content.

\section{Molecular analyses of $F_{1}$ population}

$F_{1}$ hybrid plants were identified using SSR microsatellite markers. Amplification of microsatellite markers was performed by PCR. The PCR mixture consisted of $1 \mathrm{X}$ buffer (10 mM Tris- $\mathrm{HCl}, \mathrm{pH} 8.0,50 \mathrm{mM} \mathrm{KCl}$ ), $1.5 \mathrm{mM} \mathrm{MgCl}, 0.15 \mu \mathrm{M}$ each dNTP, $0.15 \mu \mathrm{M}$ forward and reverse primers, $1 \mathrm{U}$ Taq polymerase, $300 \mathrm{ng}$ genomic DNA, and $25 \mu \mathrm{L}$ ultrapure water. The amplification program consisted of an initial denaturation at $94^{\circ} \mathrm{C}$ for $7 \mathrm{~min}$, followed by 32 cycles of denaturation at $94^{\circ} \mathrm{C}$ for $1 \mathrm{~min}$, primer specific annealing temperature for $1 \mathrm{~min}$, extension at $72^{\circ} \mathrm{C}$ for $2 \mathrm{~min}$, and a final extension at $72^{\circ} \mathrm{C}$ for $7 \mathrm{~min}$. The PCR product was electrophoresed at $80 \mathrm{~V}$ for about three hours in 1X TBE buffer on a high-resolution 3\% agarose gel (UltraPure Agarose 1000). The gel was subsequently stained with $10 \mathrm{mg} / \mathrm{mL}$ ethidium bromide, visualized under UV light, and photographed using a gel-documentation system (QUANTUM-ST4).

Twenty-seven markers of different linkage groups belonging to the soybean genetic map were used in the PCRs to check the heterozygosity of individuals obtained after intercrossing. Individuals that showed a band profile of both the locus alleles indicated the effectiveness of crossing and were identified to have originated from hybridizations; these were selected for obtaining the next generation $\left(F_{2}\right)$.

\section{Molecular analyses of $F_{2}$ population}

Molecular analyses of the $F_{2}$ population were performed in the Laboratory of Genetic Diversity and Plant Breeding located in the Genetics Department of Escola Superior de Agricultura "Luiz de Queiroz", in Piracicaba, SP, Brazil.

Bulked segregant analysis (BSA) is a quick and efficient process to identify specific genomic 
regions, which can be associated with particular phenotypic characteristics (Michelmore et al., 1991). For this analysis, the microsatellite loci (SSRs) were evaluated for the degree of polymorphism by comparing the genitors Tucunaré and Lineage 69. The loci with the greatest potential to generate polymorphic markers and produce new high-quality bands were selected. A 20-progeny bulk, with 10 progenies each containing high and low oil content, from the mapped population generated by crossing the Tucunaré cultivar (high oil content) and Lineage 69 (low oil content), was evaluated to assess the possible association of microsatellite markers with the oil content. After identification of the polymorphic markers, they were evaluated in the mapped population.

For amplification, the reaction mixture contained $20 \mathrm{ng}$ DNA, $10 \mathrm{mM}$ forward primer, 10 $\mathrm{mM}$ reverse primer, $10 \mathrm{mM}$ fluorescent M13 primer, $25 \mathrm{mM}$ each dNTP, 10X PCR buffer, $2.5 \mathrm{mg} /$ $\mathrm{mL}$ bovine serum albumin (BSA), $25 \mathrm{mM} \mathrm{MgCl}$, and $1 \mathrm{U}$ Taq DNA polymerase enzyme in a total volume of $10 \mu \mathrm{L}$. Microsatellite region amplification was performed according to the following protocol: $5 \mathrm{~min}$ at $94^{\circ} \mathrm{C}$, followed by 10 cycles of 1 -min denaturation at $94^{\circ} \mathrm{C}, 1$-min annealing at $50^{\circ} \mathrm{C}$, and $1 \mathrm{~min}$ extension at $72^{\circ} \mathrm{C}$; after each cycle the annealing temperature was decreased by $1^{\circ} \mathrm{C}$. Thereafter, 30 cycles were performed as follows: $94^{\circ} \mathrm{C}$ for $40 \mathrm{~s}, 40^{\circ} \mathrm{C}$ for $40 \mathrm{~s}$, and $72^{\circ} \mathrm{C}$ for 1 $\mathrm{min}$; this was followed by a final extension at $72^{\circ} \mathrm{C}$ for $10 \mathrm{~min}$.

The PCR products were purified by electrophoresis on a polyacrylamide gel under denaturing conditions and sequenced using an automated sequencer (LI-COR 4300S DNA Analysis System; LI-COR Biosciences, Lincoln, NE, USA). The number of base pairs in the alleles was inferred based on standard commercial markers (ladder) and the images were filed for subsequent allele labeling and genotyping using the SAGA Lite and the SAGA MX Generation software (LI-COR Corporate). The results were checked and, if necessary, allele identifications were manually corrected.

\section{Polymorphism information content (PIC)}

PIC was calculated using the formula proposed by Anderson et al. (1993), which takes into account the detected alleles, their frequency, and distribution over the studied population. PIC was estimated to determine the value of each marker in polymorphism detection among the soybean progenies. The formula is presented below:

$$
P I C_{i}=1-\sum_{j=1}^{n} p_{i j}
$$

where, $p_{i j}$ stands for the frequency of $j$ allele within the $i$ marker (summation extends over all the alleles). Calculation was based on the number of detected alleles per marker for a certain locus and relative frequency of each allele in the evaluated progeny set.

\section{Construction of the linkage map}

Linkage map was constructed using the R statistical software package, OneMap (Margarido et al., 2007). The linkage groups (LG) were established by adopting a minimum logarithm of odds (LOD) of 3.84 for connection among the markers, for ordering of marker strains, and maximum recombination 
fraction ( $r$ ) of 0.30 . The 'order.seq' function was used to determine the best order of markers within each linkage group, once the software automatically used the 'compare' and 'try.seq' functions. Distances between the markers, in centimorgans (cM), were estimated by Kosambi function.

\section{Mapping of QTL for oil content}

QTL detection and mapping analyses were carried through composite interval method (CIM; Zeng, 1994). CIM was run on model 6 of Zmapqtl, which was used as a variable selection model for the forward and backward regression. The presence of QTL was declared every $1 \mathrm{cM}$ (centimorgan) with a 10-cM window. Minimum LOD score was established using a permutation test (1000 runs) with an overall $P=0.05$. All the analyses were performed by means of a QTL cartographer, version 2.5 (Wang et al., 2012).

\section{Oil content of the progenies}

The seed oil content was obtained using a near infrared spectrometer Tango model (Bruker Co., Ltd. Germany). Spectrum readings were taken in the range between 11,536 to $3952 \mathrm{~cm}^{-1}$ with 64 scans, at $16 \mathrm{~cm}^{-1}$ resolution and $8 \mathrm{~cm}^{-1}$ interval. Percentage of oil content was obtained for all the $F_{2}$ seeds of the crosses. Because of $F_{2}$ being segregating populations, analyses were made in triplicate per seed unit. In the subsequent generation, the analyses were confirmed in the progenies derived from each individual plant $\left(F_{2: 3}\right.$ seeds); the experiment was performed in triplicate.

\section{RESULTS}

The average percentage of seed oil content estimated using triplicate NIR readings is shown in Table 2. The average seed oil content in the segregating populations of 244 progenies used for QTL mapping ranged from 14.35 to $23.53 \%$.

Among the 358 SSRs evaluated by BSA analysis, 327 (91.34\%) produced high quality band standards, of which 226 showed monomorphic strains, while 101 demonstrated polymorphism between the parents, and 10 loci presented possible relationships between high and low oil content assessed in bulk individuals. The mapped population from these genotypes was thus shown to be effective for construction of genetic maps related to soybean oil content.

From the 101 polymorphic SSRs evaluated by BSA analysis, 62 loci showed high quality bands suitable for genotyping. PIC ranged from 0.24 to 0.58 with an average of 0.37 . In a similar result, Vieira et al. (2009), who analyzed soybean cultivars, detected an average PIC of 0.40 .

A total of 56 markers from 17 LGs were used for $F_{2}$ genotyping based on the Soybean Consensus Map 4.0. Considering an LOD threshold of 3.5, two QTLs for the target trait were located on chromosome $9(\mathrm{LG}-\mathrm{K}$ ) and $12(\mathrm{LG}-\mathrm{H})$; this result was significant at $\mathrm{P}<0.05$ (Figure 1). The QTL identified on chromosome 9 ( $L G-K)$ accounted for $7.8 \%$ phenotypic variation, while that on chromosome $12(\mathrm{LG}-\mathrm{H}$ ) was responsible for $46.75 \%$ variation (Table 3 ). 
Table 2. Seed oil content in 244 progenies obtained from the cross between the Tucunare cultivar and Lineage 69, which were used for QTL mapping.

\begin{tabular}{|c|c|c|c|c|c|c|c|c|c|}
\hline$F_{2}$ & Average (\%) & $\mathrm{F}_{2}$ & Average (\%) & $\mathrm{F}_{2}$ & $\begin{array}{c}\text { Average } \\
(\%)\end{array}$ & $\mathrm{F}_{2}$ & Average (\%) & $\mathrm{F}_{2}$ & $\begin{array}{c}\text { Average } \\
(\%)\end{array}$ \\
\hline $\mathrm{C} 23 \mathrm{P} 1$ & 20.057 & C23P62 & 19.070 & C23P158 & 17.910 & C23P228 & 19.953 & C23Р301 & 18.846 \\
\hline $\mathrm{C} 23 \mathrm{P} 2$ & 19.173 & C23P63 & 17.888 & C23P159 & 17.894 & C23P229 & 19.753 & С23Р302 & 21.273 \\
\hline $\mathrm{C} 23 \mathrm{P} 3$ & 20.647 & C23P64 & 19.115 & C23P160 & 17.543 & $\mathrm{C} 23 \mathrm{P} 233$ & 20.223 & С23Р 303 & 19.626 \\
\hline $\mathrm{C} 23 \mathrm{P} 4$ & 20.809 & C23P65 & 21.939 & C23P161 & 18.616 & C23P234 & 19.233 & C23Р 304 & 19.452 \\
\hline C23P5 & 20.574 & C23P67 & 20.213 & C23P162 & 16.934 & C23P235 & 17.245 & C23P305 & 18.744 \\
\hline $\mathrm{C} 23 \mathrm{P} 6$ & 18.911 & C23P68 & 14.601 & C23P163 & 18.013 & C23P238 & 19.632 & С23Р 306 & 19.325 \\
\hline $\mathrm{C} 23 \mathrm{P} 7$ & 20.762 & C23P70 & 15.810 & C23P164 & 16.496 & C23P240 & 17.982 & C23P307 & 19.841 \\
\hline C23P8 & 20.986 & C23P71 & 21.582 & C23P165 & 16.394 & C23P241 & 18.173 & C23P308 & 20.894 \\
\hline $\mathrm{C} 23 \mathrm{P} 9$ & 18.920 & $\mathrm{C} 23 \mathrm{P} 72$ & 19.071 & C23P166 & 19.624 & C23P242 & 19.647 & С23Р309 & 20.637 \\
\hline C23P10 & 22.435 & C23P75 & 19.777 & C23P167 & 18.685 & C23P243 & 20.456 & C23P310 & 20.751 \\
\hline C23P11 & 19.517 & $\mathrm{C} 23 \mathrm{P} 77$ & 20.342 & C23P168 & 18.290 & $\mathrm{C} 23 \mathrm{P} 248$ & 15.643 & $\mathrm{C} 23 \mathrm{P} 311$ & 19.130 \\
\hline $\mathrm{C} 23 \mathrm{P} 12$ & 22.529 & C23P79 & 20.531 & C23P169 & 18.762 & $\mathrm{C} 23 \mathrm{P} 251$ & 21.932 & С23Р 312 & 19.257 \\
\hline C23P13 & 22.275 & C23P80 & 18.631 & C23P170 & 17.066 & C23P252 & 23.166 & C23P313 & 18.316 \\
\hline C23P14 & 20.341 & C23P81 & 20.576 & C23P172 & 17.093 & C23P254 & 19.960 & C23P314 & 18.819 \\
\hline C23P15 & 17.149 & C23P82 & 19.704 & C23P173 & 19.523 & C23P255 & 18.770 & C23P315 & 19.462 \\
\hline C23P16 & 18.307 & C23P83 & 21.238 & C23P175 & 19.089 & C23P256 & 19.475 & C23P316 & 19.690 \\
\hline C23P20 & 21.120 & C23P84 & 17.222 & C23P177 & 17.733 & C23P257 & 17.459 & C23P318 & 18.703 \\
\hline $\mathrm{C} 23 \mathrm{P} 21$ & 17.132 & C23P86 & 16.995 & C23P178 & 19.110 & C23P261 & 20.343 & C23P319 & 17.063 \\
\hline $\mathrm{C} 23 \mathrm{P} 22$ & 19.145 & C23P87 & 20.147 & C23P181 & 18.646 & C23P262 & 18.121 & $\mathrm{C} 23 \mathrm{P} 320$ & 17.777 \\
\hline $\mathrm{C} 23 \mathrm{P} 23$ & 20.250 & C23P88 & 18.848 & C23P182 & 17.78 & C23P263 & 20.324 & C23P321 & 17.014 \\
\hline C23P24 & 20.090 & C23P93 & 19.415 & C23P183 & 18.843 & C23P264 & 18.375 & C23P322 & 17.549 \\
\hline $\mathrm{C} 23 \mathrm{P} 25$ & 20.901 & C23P96 & 18.084 & C23P185 & 18.641 & $\mathrm{C} 23 \mathrm{P} 265$ & 19.872 & C23P323 & 18.668 \\
\hline C23P26 & 21.660 & C23P97 & 19.167 & C23P186 & 18.299 & C23P266 & 20.864 & C23P324 & 19.517 \\
\hline $\mathrm{C} 23 \mathrm{P} 27$ & 20.673 & C23P99 & 23.344 & C23P188 & 20.773 & C23P267 & 19.616 & C23P325 & 19.039 \\
\hline C23P28 & 20.977 & C23P101 & 18.614 & C23P189 & 17.279 & C23P268 & 19.779 & C23P326 & 19.846 \\
\hline C23P29 & 22.864 & C23P102 & 21.664 & C23P191 & 19.738 & C23P271 & 19.566 & C23P327 & 20.601 \\
\hline C23P31 & 20.007 & $\mathrm{C} 23 \mathrm{P} 114$ & 19.467 & C23P192 & 15.782 & $\mathrm{C} 23 \mathrm{P} 272$ & 20.835 & C23P328 & 19.397 \\
\hline C23P32 & 21.398 & C23P116 & 19.017 & C23P194 & 14.820 & $\mathrm{C} 23 \mathrm{P} 273$ & 19.797 & C23P329 & 18.811 \\
\hline C23P33 & 20.039 & C23P122 & 18.640 & C23P197 & 19.166 & C23P274 & 20.524 & C23P330 & 19.691 \\
\hline C23P34 & 21.348 & $\mathrm{C} 23 \mathrm{P} 124$ & 16.765 & C23P198 & 18.782 & $\mathrm{C} 23 \mathrm{P} 275$ & 19.557 & C23P331 & 19.779 \\
\hline $\mathrm{C} 23 \mathrm{P} 35$ & 19.271 & $\mathrm{C} 23 \mathrm{P} 125$ & 23.232 & C23P199 & 14.549 & $\mathrm{C} 23 \mathrm{P} 277$ & 19.720 & $\mathrm{C} 23 \mathrm{P} 332$ & 14.945 \\
\hline C23P36 & 17.851 & C23P127 & 20.99 & C23P201 & 18.604 & C23P281 & 20.524 & C23Р334 & 20.445 \\
\hline C23P37 & 17.991 & C23P129 & 20.800 & C23P202 & 19.228 & C23P282 & 19.169 & C23P336 & 17.286 \\
\hline C23P38 & 21.763 & $\mathrm{C} 23 \mathrm{P} 131$ & 19.227 & C23P203 & 17.690 & $\mathrm{C} 23 \mathrm{P} 284$ & 19.240 & C23P337 & 19.336 \\
\hline C23P39 & 18.825 & C23P133 & 19.837 & C23P206 & 19.630 & C23P285 & 20.378 & C23P338 & 17.792 \\
\hline $\mathrm{C} 23 \mathrm{P} 40$ & 23.531 & C23P134 & 19.493 & C23P209 & 16.942 & C23P286 & 19.595 & C23P341 & 19.972 \\
\hline C23P41 & 18.048 & C23P135 & 19.959 & C23P210 & 19.398 & C23P287 & 20.688 & C23P344 & 18.559 \\
\hline $\mathrm{C} 23 \mathrm{P} 42$ & 19.600 & C23P137 & 22.349 & C23P212 & 19.062 & C23P288 & 19.884 & C23P345 & 15.399 \\
\hline $\mathrm{C} 23 \mathrm{P} 43$ & 20.159 & C23P140 & 19.121 & C23P215 & 20.735 & C23P289 & 18.525 & C23P346 & 14.406 \\
\hline C23P44 & 19.277 & C23P144 & 17.988 & C23P216 & 18.434 & C23P290 & 20.428 & C23P347 & 17.865 \\
\hline C23P45 & 18.832 & C23P145 & 23.477 & C23P217 & 19.285 & C23P291 & 19.228 & C23P348 & 19.097 \\
\hline $\mathrm{C} 23 \mathrm{P} 46$ & 17.308 & C23P146 & 21.312 & C23P218 & 19.694 & C23P292 & 19.679 & C23P349 & 20.659 \\
\hline C23P47 & 18.979 & C23P147 & 14.349 & C23P219 & 18.229 & C23P293 & 17.866 & C23P351 & 21.052 \\
\hline C23P49 & 18.938 & C23P148 & 17.705 & C23P220 & 21.358 & C23P295 & 19.009 & C23P352 & 19.330 \\
\hline $\mathrm{C} 23 \mathrm{P} 50$ & 21.221 & C23P151 & 17.638 & C23P222 & 17.443 & C23P296 & 21.513 & C23P 355 & 17.320 \\
\hline
\end{tabular}

Continued on next page 
Table 2. Continued.

\begin{tabular}{l|c|c|c|c|c|c|c|c|c}
\hline $\mathrm{F}_{2}$ & Average $(\%)$ & $\mathrm{F}_{2}$ & Average $(\%)$ & $\mathrm{F}_{2}$ & $\begin{array}{c}\text { Average } \\
(\%)\end{array}$ & $\mathrm{F}_{2}$ & Average $(\%)$ & $\mathrm{F}_{2}$ & $\begin{array}{c}\text { Average } \\
(\%)\end{array}$ \\
\hline C23P55 & 22.447 & $\mathrm{C} 23 \mathrm{P} 152$ & 17.061 & $\mathrm{C} 23 \mathrm{P} 224$ & 18.645 & $\mathrm{C} 23 \mathrm{P} 297$ & 18.625 & C23P357 & 21.305 \\
\hline C23P56 & 20.680 & $\mathrm{C} 23 \mathrm{P} 153$ & 17.157 & $\mathrm{C} 23 \mathrm{P} 225$ & 17.780 & C23P298 & 17.927 & C23P363 & 18,336 \\
\hline C23P57 & 17.004 & C23P154 & 19.460 & C23P226 & 18.982 & C23P299 & 19.382 & C23P30 & 19.660 \\
\hline C23P58 & 19.425 & C23P157 & 17.057 & C23P227 & 18.838 & C23P300 & 19.409 & & \\
\hline
\end{tabular}

$\mathrm{C}=$ crossing; $\mathrm{P}=$ plant.

Chr-9

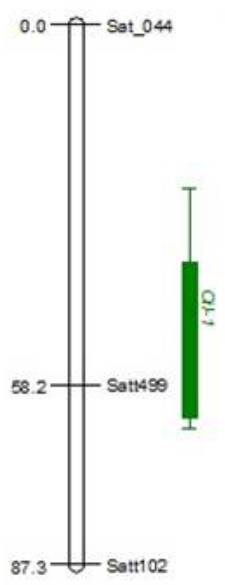

Chr-12

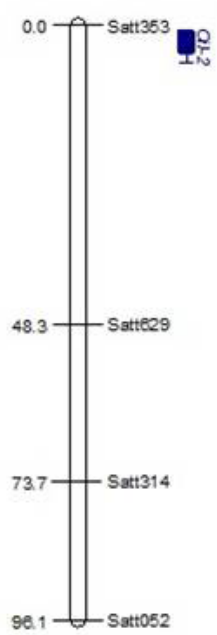

Figure 1. Linkage groups of the $F_{2}$ population consisted of 244 progenies of soybean generated by crossing Lineage 69 and the Tucunare cultivar, and LOD of 3.84 was used as a criterion. To the left are the distances between the markers, and to the right are the identifications.

Table 3. QTLs for soybean seed oil content evaluated in 244 progenies obtained from the crossing of Lineage 69 and the Tucunaré cultivar.

\begin{tabular}{l|c|c|c|c}
\hline Chromosome & LG & Position (cM) & Markers & $\mathrm{R}^{2}(\%)$ \\
\hline Chr-9 & K & $41-55$ & Sat_044 - Satt499 & 7.8 \\
\hline Chr-12 & H & $0-14$ & Satt353 - Satt629 & 46.75 \\
\hline Total & & & & 54.55 \\
\hline
\end{tabular}

$\mathrm{LG}=$ linkage group; $\mathrm{cM}=$ centimorgans; $\mathrm{R}^{2}$ = recombination frequency.

\section{DISCUSSION}

Previous studies have demonstrated the existence of QTLs for soybean oil content at different regions along the soybean genome. Several authors (Mansur et al., 1996; Brummer et al., 1997; Specht et al., 2001) have reported other quantitative loci with different magnitudes, locations, and genetic populations. 
Others researchers (Sebolt et al., 2000; Csanádi et al., 2001; Chung et al., 2003; Reinprecht et al., 2006) have also demonstrated the genomic regions involved in the control of oil content in different soybean populations. These observations validate the association of markers with the trait assessed in the present study.

Association of LG I with this trait has been previously reported by several authors. Chung et al. (2003) mapped the QTLs that explained 27.8 and $24.2 \%$ of the variation in oil content in the years of 1996 and 1999, respectively. Tajuddin et al. (2003) used 157 RILs and mapped QTLs at the Satt239 region to explain an $8.6 \%$ variation in the oil content variation over a period of two years.

Panthee et al. (2005) detected QTLs for oil and protein contents in a population of 101 RILs derived from crosses between N98-984 and TN93-99. Among the 585 SSRs tested by these authors, 94 markers were polymorphic in the evaluated population. One QTL in LG G accounted for about $20 \%$ of the protein content and three QTLs in D1b, G, and O linkage groups explained 11.8, 9.4 , and $15.0 \%$ of the oil content in this population.

Moreover, Nichols et al. (2006) studied different populations of $\mathrm{RC}_{4} \mathrm{~F}_{3: 4}$ and $\mathrm{RC}_{5} \mathrm{~F}_{5}$ isoline for oil and protein contents using AFLP and SSR markers of LG I. In the $R_{4} F_{3: 4}$ populations, these authors mapped one QTL for protein and oil content within $11 \mathrm{cM}$ interval between Satt614 and Satt354. When analyzing the $\mathrm{RC}_{5} \mathrm{~F}_{5}$ populations, the location of this QTL was redefined to $3 \mathrm{cM}$ interval between Satt239 and ACG9b; this accounted for 15.4, 11.7, 17.7, and 21.1\% variation in the protein content for each $\mathrm{RC}_{5} \mathrm{~F}_{5}$ population.

Oil content related loci at Satt239 LG I were reported by several authors in different genetic backgrounds and environments. This indicates conserved genes within the region, thereby, validating the presence of this locus in the genome of species; this has a great importance for the genetic mapping of oil content to accurately determine the QTL location. Furthermore, the same intervals that revealed the pleiotropic effects of one or more genes in the region also affected the protein content.

A genetic study of oil and protein contents in Glycine max x Glycine soja revealed normal distribution and high heritability in $\mathrm{F}_{2}$ and recombinant populations; moreover, there was a negative correlation between such characters. A QTL for lipid content and concentration of linoleic acid was detected within the same position near Satt384 SSR marker in L, G, and E groups, suggesting that those QTLs responsible for linoleic acid can simultaneously control the lipid content partially (Shibata et al., 2008).

Within the LG A1, between Satt200 and Satt225 strains, the QTL for oil content was detected, which accounted for $17.3 \%$ of the trait variation. In addition, the Satt236 marker associated with oil content explained 5.2\% variation (Rodrigues et al., 2010).

Rodrigues et al. (2010) studied 207 progenies obtained from the crosses between Lineage CS3032PTA276 and UFS2012 variety. These authors evaluated 357 SSR loci pairs for polymorphism of parent populations; of these about 100 loci were polymorphic and 48 markers among these 100 loci were amplified. Such a choice was made because of their proximity to genome areas in which QTLs related to soybean seed oil and protein contents were previously reported. Therefore, nine linkage groups were generated covering genomic segments of $A 1, B 1$, D1a, G, I, M, and O groups. Sixteen markers had significant association, explaining 3.1 to $25.4 \%$ phenotypic value, while 13 markers were also linked to the protein content. This result reflects the likelihood that common regions simultaneously act to control two distinct traits. Thus, the highest $\mathrm{R}^{2}$ values for both the protein and oil content were observed for the same marker, Satt239, from LG I indicating that this region greatly affected the QTL for both the characteristics. These values are in agreement to those obtained in the present study.

Shi et al. (2010), working with 150 soybean genotypes, evaluated 65 microsatellite 
markers to map oil and protein contents. Of those, 13 were found to be associated with the oil content and 19 with the protein content and these were distributed among 11 and 14 linkage groups, respectively, with 12 linked to both the parameters, simultaneously.

It was observed that the QTLs for oil and protein contents in the two groups of soybean cultivars and lines were distinct for the different microsatellite markers and environments. Overall, microsatellite markers specific for both the oil and protein levels were found, signifying a pleiotropic effect on both the parameters. With respect to the oil content, 21 associations were observed in group I. In this group, 21 associations were also observed for the protein content. However, in group II, 41 associations were observed for the oil content whereas 38 were found for the protein content. Generally, 13 markers were associated with both the characteristics; Sat239, Satt384, and Satt562 were significant for the assisted selection for the oil and protein content, whereas Satt310 was specific for the selection of oil content and Satt567 for the protein content as assessed by their respective magnitudes under different growth environments (Rodrigues et al., 2013).

Comparing the current genetic map with the others obtained from bi-parental crossings of elite lineage and cultivars, it is noteworthy that the Lineage $69 \times$ Tucunaré cultivar map was biased, necessitating the need to include new markers. Population derived from this cross demonstrated sufficient genetic variability both for seed oil content and for polymorphism at the molecular marker level. Therefore, such information warrants further studies for QTL detection and mapping for the same trait to validate the results of this study.

In conclusion, major and minor QTLs were found for soybean oil content in the mapped population. QTLs not mentioned in previous studies were mapped on linkage group $\mathrm{K}$, which is considered less significant (Sat_044 - Satt499), but higher in linkage group H (Satt353 - Satt629). These QTLs may contribute to saturate the mapping of seed oil content, in addition to being used for assisted-selection in breeding programs.

\section{Conflicts of interest}

The authors declare no conflicts of interest.

\section{ACKNOWLEDGMENTS} Research
\#2011/00625-5).

\section{REFERENCES}

Anderson JA, Churchill GA, Autrique JE, Tanksley SD, et al. (1993). Optimizing parental selection for genetic linkage maps. Genome 36: 181-186. http://dx.doi.org/10.1139/g93-024

Brummer EC, Graef GL, Orf JH, Wilcox R, et al. (1997). Mapping QTL for seed protein and oil content in eight soybean populations. Crop Sci. 37: 370-378. http://dx.doi.org/10.2135/cropsci1997.0011183X003700020011x

Cato SA, Gardner RC, Kent J and Richardson TE (2001). A rapid PCR-method for genetically mapping ESTs. Theor. Appl. Genet. 102: 296-306. http://dx.doi.org/10.1007/s001220051646

Chung J, Babka HL, Graef GL, Staswick PE, et al. (2003). The seed protein, oil, and yield QTL on soybean linkage group I. Crop Sci. 43: 1053-1067. http://dx.doi.org/10.2135/cropsci2003.1053

Csanádi G, Vollmann J, Stift G and Lelley T (2001). Seed quality QTLs identified in a molecular map of early maturing soybean. Theor. Appl. Genet. 103: 912-919. http://dx.doi.org/10.1007/s001220100621

Ferreira ME and Grattapaglia D (1998). Introdução ao uso de marcadores moleculares em análise genética. 3 edn. EMBRAPACENARGEN, Brasília. 
Mansur LM, Orf JH, Chase K, Jarvik T, et al. (1996). Genetic mapping of agronomic traits using recombinant inbred lines of soybean. Crop Sci. 36: 1327-1336. http://dx.doi.org/10.2135/cropsci1996.0011183X003600050042x

Margarido GR, Souza AP and Garcia AA (2007). OneMap: software for genetic mapping in outcrossing species. Hereditas 144: 78-79. http://dx.doi.org/10.1111/j.2007.0018-0661.02000.x

Michelmore RW, Paran I and Kesseli RV (1991). Identification of markers linked to disease-resistance genes by bulked segregant analysis: a rapid method to detect markers in specific genomic regions by using segregating populations. Proc. Natl. Acad. Sci. U. S. A. 88: 9828-9832. http://dx.doi.org/10.1073/pnas.88.21.9828

Nichols DM, Glover KD, Carlson SR, Specht JE, et al. (2006). Fine mapping of a seed protein QTL on soybean linkage group I and its correlated effects on agronomic traits. Crop Sci. 46: 834-839. http://dx.doi.org/10.2135/cropsci2005.05-0168

Panthee DR, Pantalone VR, West DR, Saxton AM, et al. (2005). Quantitative trait loci for seed protein and oil concentration and seed size in soybean. Crop Sci. 45: 2015-2022. http://dx.doi.org/10.2135/cropsci2004.0720

Powell W, Machray GC and Provan J (1996). Polymorphism revealed by simple sequence repeats. Trends Plant Sci. 1: 215222. http://dx.doi.org/10.1016/S1360-1385(96)86898-0

Reinprecht Y, Poysa VW, Yu K, Rajcan I, et al. (2006). Seed and agronomic QTL in low linolenic acid, lipoxygenase-free soybean (Glycine max (L.) Merrill) germplasm. Genome 49: 1510-1527. http://dx.doi.org/10.1139/g06-112

Rodrigues JIS, Miranda FD, Ferreira A, Borges LL, et al. (2010). Mapeamento de QTL para conteúdos de proteína e óleo em soja. Pesq. Agropec. Bras. 45: 472-480. http://dx.doi.org/10.1590/S0100-204X2010000500006

Rodrigues JIS, Arruda KMA, Cruz CD, Piovesan ND, et al. (2013). Associação de marcadores microssatélites com teores de óleo e proteína em soja. Pesq. Agropec. Bras. 48: 255-262. http://dx.doi.org/10.1590/S0100-204X2013000300003

Sebolt AM, Shoemaker RC and Diers BW (2000). Analysis of a quantitative trait locus allele from wild soybean that increases seed protein concentration in soybean. Crop Sci. 40: 1438-1444. http://dx.doi.org/10.2135/cropsci2000.4051438x

Shi A, Chen P, Zhang B and Hou A (2010). Genetic diversity and association analysis of protein and oil content in foodgrade soybeans from Asia and the United States. Plant Breed. 129: 250-256. http://dx.doi.org/10.1111/j.1439-0523.2010.01766.x

Shibata M, Takayama K, Ujiie A, Yamada T, et al. (2008). Genetic relationship between lipid content and linolenic acid concentration in soybean seeds. Breed. Sci. 58: 361-366. http://dx.doi.org/10.1270/jsbbs.58.361

Specht JE, Chase K, Macrander M, Graef BL, et al. (2001). Soybean response to water. Crop Sci. 41: 493-509. http://dx.doi. org/10.2135/cropsci2001.412493x

Tajuddin T, Watanabe S, Yamanaka N and Harada K (2003). Analysis of quantitative trait loci for protein and lipid contents in soybean seeds using recombinant inbred lines. Breed. Sci. 53: 133-140. http://dx.doi.org/10.1270/jsbbs.53.133

Toledo ER, Leandro RA, Souza CL, Jr. and Souza AP (2008). Mapeamento de QTLs: uma abordagem Bayesiana. Rev. Bras. Biol. 26: 107-114.

Vieira ESN, Schuster I, Silva RB and Oliveira MAR (2009). Variabilidade genética em cultivares de soja determinada com marcadores microssatélites em gel de agarose. Pesq. Agropec. Bras. 44: 1460-1466. http://dx.doi.org/10.1590/S0100204X2009001100013

Wang S, Basten CJ and Zeng ZB (2012). Windows QTL cartographer 2.5. North Carolina State University, Raleigh.

Zeng ZB (1994). Precision mapping of quantitative trait loci. Genetics 136: 1457-1468. 